\title{
WORKPLLBE SOLDIONS
}

\section{Preventing Worker Deaths from Trench Cave-ins}

\section{Summary}

Workers are at risk of death from cave-ins during trenching and excavation activities. NIOSH recommends engineering controls, protective equipment, and safe work practices to minimize hazards for workers.

\section{Description of Exposure}

Workers who dig or excavate trenches are at risk of death if they enter an unprotected trench and the walls collapse. However, hazards associated with trench work and excavation are well defined and preventable. The OSHA standard for excavation and trenching, known as 29 CFR $^{*} 1926$ Subpart P, describes the precautions needed for safe excavation work.

There is no reliable warning when a trench fails. The walls can collapse suddenly, and workers will not have time to move out of the way. Even though small amounts of dirt may not seem

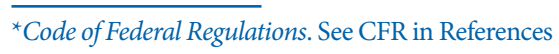

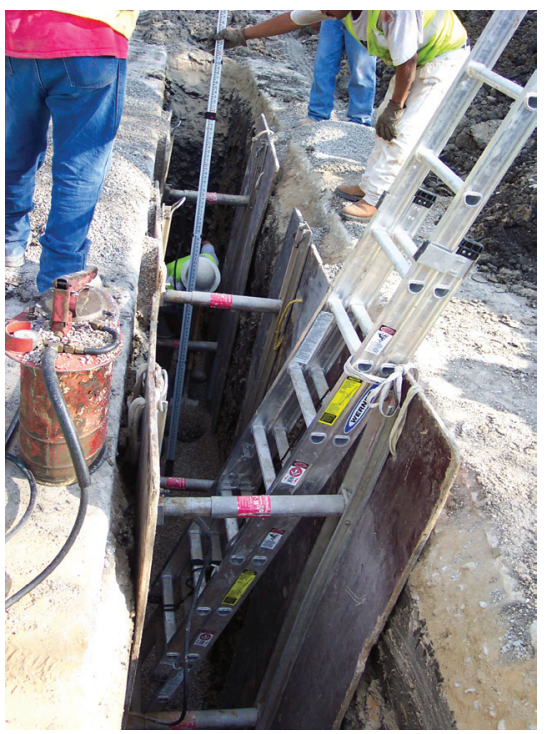

Figure 1. Work crew installing water pipes. Aluminum hydraulic shoring is being used as a protective system for the trench. Photo courtesy of George Kennedy, NUCA.

treacherous, a single cubic yard of dirt can weigh more than 3,000 pounds, which can fatally crush or suffocate workers [Deatherage et al. 2004]. Even small, solid pieces of dirt can cause serious injuries.

From 2000-2009, 350 workers died in trenching or excavation cave-ins-an average of 35 fatalities per year [BLS 2010]. Most incidents involve excavation work or "water, sewer, pipeline, and communications and power-line construction" [CDC 2004]. An analysis of OSHA data from 1997-2001 showed that $64 \%$ of fatalities in trenches occurred at depths of less than 10 feet [Arboleda and Abraham 2004].

Lack of a protective system was the leading cause of trench-related fatalities in a review of OSHA inspections [Deatherage et al. 2004]. OSHA requires that all excavations 5 feet deep or greater make use of one of the following protective system options (see Figure 1): (1) sloping the ground; (2) benching the ground; ${ }^{\dagger}$ (3) shoring the trench with supports such as planking or hydraulic jacks, or (4) shielding the trench (using a trench box). Workers should never enter a trench that does not have a protective system in place designed and installed by a competent person. ${ }^{\ddagger}$

Factors such as type of soil, water content of soil, environmental conditions, proximity to previously backfilled excavations, weight of heavy equipment or tools, and vibrations from machines and motor vehicles can greatly affect soil

\footnotetext{
${ }^{\dagger}$ Not all protective systems can be used in all types of soil. Benching cannot be used in Type C soil.

${ }^{*} \mathrm{~A}$ competent person is one who understands OSHA regulations, can recognize hazards, and is authorized to correct them.
}

DEPARTMENT OF HEALTH AND HUMAN SERVICES Centers for Disease Control and Prevention National Institute for Occupational Safety and Health

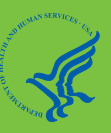

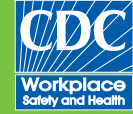

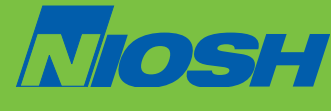


stability and the hazards that workers face. When the sides of trenches are shored, the type of soil and width and depth of the trench affect how far apart the supports should be spaced. Different OSHA regulations apply to the different types of supports used for shoring. Consult 29 CFR 1926 Subpart P Appendices $\mathrm{C}$ and $\mathrm{D}$ for more information. Appendix F provides a flow diagram for making decisions. Section V, Chapter 2 of the OSHA Technical Manual provides a guide on recognizing and preventing trenching and shoring hazards.

The following case studies, from the NIOSH Fatality Assessment and Control Evaluation Program, describe two fatalities in which workers suffocated during trench collapses.

\section{Case Studies}

\section{Case 1: Male Hispanic Laborer Dies When 9-Foot-Deep Trench Collapses}

On February 1, 2006, a 29-year-old male Hispanic laborer with 5 years of experience died when the 2-foot-wide, 16-foot-long, and 9-foot-deep unprotected trench he was working in collapsed and covered him with soil during waterproofing work. The victim and four other laborers, all of whom spoke primarily Spanish and very little English, had been hand digging the trench over a 2-day period at a private residence. The victim was kneeling to inspect a broken drain pipe at the bottom of the east end of the trench. The victim's brother saw the soil strike the victim and knock his head against the home's basement wall. The trench wall collapsed and the victim was completely covered with soil in seconds. The victim was pronounced dead at the scene by emergency response personnel. The company did not have a written safety and health program, competent person on site, or safety committee [NIOSH 2006].

\section{Case 2: Construction Laborer Dies when Trench Walls Collapse}

On November 3, 2003, a 38-year-old male construction laborer died when the unprotected, 8-foot-high walls of the trench he was working in collapsed only a few minutes after he had entered. The victim was removing an old gas line that was a 6-inch diameter high pressure line (300-320 psi) in 10-inch steel casing. Five workers were at the job site excavating the gas line: a foreman who was a competent person, a lab technician who was a competent person, and 3 laborers (including the victim). The foreman had dug an 8-foot deep trench with a track hoe to expose the abandoned gas line. After the gas line was extracted from its casing, the victim climbed into the trench with a saw to free the casing, a job that the report indicated would only take a few minutes. Sloping, benching, or shoring methods were not used to support the trench. As the laborer began sawing, the sides of the trench collapsed, burying him. He was declared dead at the scene [NIOSH 2003].

\section{Recommendations}

[Mulhern and Lentz 2008, 2009]

\section{Employers}

\section{Pre-job Planning Before the Job Begins}

- Train and designate a competent person to ensure safety measures are in place.

- Call 811 before digging so that utility lines can be marked, then "pot-hole" utilities to determine the exact location and depth before digging.

- Have a competent person evaluate the soil to determine its stability. Because soil conditions can vary dramatically over just a few days, Appendix A of Subpart P provides techniques (roll test and thumb penetration) for evaluating the condition of the soil.

- Plan the job layout to identify safe locations (away from the trench) for spoil piles and heavy equipment routes.

- Have a competent person determine what type of protective system will be used for the job and schedule the steps needed to have the system complete and in place before workers enter.

- Trenches greater than 20 feet deep can be more complex. The competent person may choose a manufactured protective system with the appropriate depth rating, or use a registered professional engineer to design a site-specific protective system. Refer to 29 CFR 1926 Subpart P for requirements.

- Ensure that none of the workers designated for entry into the trench are under age 18.

- Ensure that workers involved in the job are trained about hazards and work practices in a language that they understand and at the appropriate literacy level.

- Develop a trench emergency action plan [NIOSH 2006] to describe steps to be taken and to provide contact information in case of an emergency.

\section{Safe Operations During the Job}

- The competent person must inspect the excavation, adjacent areas, and protective systems each day before the start of work, as needed throughout the shift, and after every rainstorm.

- Notify other subcontractors who come on site of the trench location and precautions and ensure that vehicles are kept a safe distance from the excavation. 
- Ensure that ladders and other means of exit from the trench are repositioned so that ladders are never more than 25 feet away from any worker in the trench.

- The competent person must remove workers from the excavation upon any evidence of a situation that could cause a cave-in, such as accumulation of water in the trench or protective system problems. (The competent person must also take actions for other types of hazards such as falling loads or hazardous atmospheres.)

- Monitor other types of trench-related hazards that can occur such as falls from the edge, rigging hazards, or toxic and combustible gases.

- Implement and enforce procedures to ensure that work in an unprotected trench is not allowed.

\section{Workers}

- Do not enter an uprotected trench, even for a short task.

- Inspect the protected trench before entering.

- Exit the trench and call the competent person if you see any evidence of problems with a protective system.

- Do not assume there will be a warning sign before a cave in or that you will have time to move out of the way.

\section{Owners and Clients}

- Insist on trench safety practices when you commission work [Thompson and Tannenbaum 1977].

- Put trench safety into bid documents and contractor qualifications.

\section{Acknowledgments}

This document was developed by T.J. Lentz, Susan Afanuh, and Matt Gillen, National Institute for Occupational Safety and Health.

\section{References}

Arboleda CA, Abraham DM [2004]. Fatalities in trenching operations analysis using models of accident causation. J Const Eng Mgmt 130(2):273-280.

BLS [2010]. Census of fatal occupational injuries (2000-2009). Washington, D.C. Bureau of Labor Statistics.

CDC [2004]. Occupational fatalities during trenching and excavation work United States, 1992-2001. MMWR 53(15):311314. http://www.cdc.gov/mmwr/preview/mmwrhtml/ mm5315a2.htm

CFR. Code of Federal regulations. Washington, DC: U.S. Government Printing Office, Office of the Federal Register. Deatherage JH, Furches LK, Radcliffe M, Schriver WR, Wagner JP [2004]. Neglecting safety precautions may lead to trenching fatalities. Am J Ind Med 45:522-527.

Mulhern B, Lentz TJ [2008]. Coming out of the trenches... safely. Hard Hat News Nov. http://hardhat.com/ME2/Audiences/dirmod.asp?sid=D8F3EF8405924C33B5F670EB0 A95DCE2\&nm=Association+News\&type=Publishing\&m od=Publications\%3A\%3AArticle $\&$ mid $=8$ F3A7027421841 978F18BE895F87F791\&id=474F54A087824914BC785DE 9FFC92DA9\&tier $=4$

Mulhern B, Lentz TJ [2009]: Trenching, Part 2: Steps for employers. Landscape Management, February 4.

NIOSH [2003]. 38 year-old construction laborer dies when trench walls collapse. http://www.cdc.gov/niosh/face/ stateface/ky/03KY107.html

NIOSH [2006]. 29-year old male Hispanic landscape laborer dies when nine foot deep trench collapses._http://www.cdc. gov/niosh/face/stateface/mi/06mi004.html

OSHA. Excavations: hazard recognition in trenching and shoring. OSHA Technical Manual, Section V, Chapter 2. Washington, DC: U.S. Department of Labor, Occupational Safety and Health Administration. http://www.osha.gov/ dts/osta/otm/otm_v/otm_v_2.html

Thompson L, Tannenbaum R [1977]. Responsibility for trenching excavation and design. J Geotech Eng Division 103(4):327-338. http://cedb.asce.org/cgi/wwwdisplay. cgi?7322 


\section{DEPARTMENT OF HEALTH AND HUMAN SERVICES}

Centers for Disease Control and Prevention

National Institute for Occupational Safety and Health

4676 Columbia Parkway

Cincinnati, OH 45226-1998

Official Business

Penalty for Private Use $\$ 300$

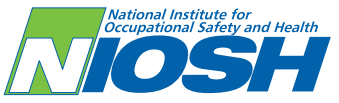

\section{For More Information}

More information about trenching and excavation can be found on the NIOSH Web site:

\section{http://www.cdc.gov/niosh/topics/trenching/}

To receive copies of the NIOSH field study reports that formed the basis of this document or to obtain information about other occupational safety and health topics, contact $\mathrm{NIOSH}$ at

Telephone: 1-800-CDC-INFO (1-800-232-4636)

TTY: 1-888-232-6348 . E-mail: cdcinfo@cdc.gov

or visit the NIOSH Web site at www.cdc.gov/niosh.

For a monthly update on news at NIOSH, subscribe to NIOSH eNews by visiting www.cdc.gov/niosh/eNews.

Mention of any company or product does not constitute endorsement by NIOSH. In addition, citations to Web sites external to NIOSH do not constitute NIOSH endorsement of the sponsoring organizations or their programs or products. Furthermore, NIOSH is not responsible for the content of these Web sites.
This document is in the public domain and may be freely copied or reprinted. NIOSH encourages all readers of the Workplace Solutions to make them available to all interested employers and workers.

As part of the Centers for Disease Control and Prevention, NIOSH is the Federal agency responsible for conducting research and making recommendations to prevent workrelated illness and injuries. All Workplace Solutions are based on research studies that show how worker exposures to hazardous agents or activities can be significantly reduced.

\section{Preventing Worker Deaths from Trench Cave-Ins}

DHHS (NIOSH) Publication No. 2011-208

(Supersedes 2011-180) 